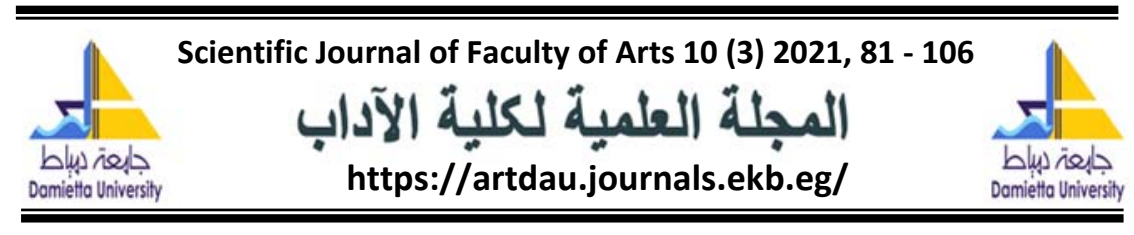

\title{
Lexical Ambiguity and Verbal Humor in Some English Jokes and Riddles
}

\section{Reham Abdelkaream Abdelhamid Makroum}

Assistant lecturer - Eng. Depart. - Faculty of Arts - Damietta University

Abstract

Linguistic ambiguity is a pervasive phenomenon in language. It occurs when a word, phrase, or sentence has more than one meaning. Although it is often considered a problem since it may cause confusion and hinder the precise understanding of language, it has its own value. Linguistic ambiguity enriches language and produces positive effects such as creating irony and adding a sort of humor. This study focuses on how lexical ambiguity, one type of linguistic ambiguity, can be a source of verbal humor. The data of the study are 20 examples of jokes and riddles that are taken from three internet sites; each example relies on lexical ambiguity. The data are analyzed to identify the words that contain lexical ambiguity in the selected jokes and riddles, classify them into the forms of lexical ambiguity, i.e., homonymy with its three subtypes (absolute homonymy, homophone and homograph) and polysemy showing the frequency of each form, and illustrate how lexical ambiguity can create a sort of humor in the light of the Incongruity Theory of humor. The results of the data analysis show that lexical ambiguity can create verbal humor according to the Incongruity Theory of humor.

Keywords: Lexical ambiguity, Verbal Humor, Absolute Homonymy, Homophone, Polysemy

\section{Article history:}

Received 24 May 2021

Received in revised form 22 June 2021.

Accepted 10 July 2021 


\section{Introduction}

Ambiguity is a fundamental linguistic feature that can be found at different levels of language. McGregor (2015) defines ambiguity as " the situation in which a word, a phrase or larger unit has multiple meanings ", (p.411). This means that ambiguity occurs when a single linguistic form has more than one meaning. For example, in a sentence like "John went to the bank", the word "bank" has several meanings including "financial institution" and "bank of a river"; therefore, this sentence is ambiguous between two interpretations: either (a) John went to the bank for money, or (b) John went to the river bank. Ambiguity in this case is a problem since it is not clear which interpretation is intended. However, ambiguity does not always play a negative role since it plays a positive role as well. This is apparent when ambiguity is used to create a sense of humor.

Humor is something that can be found in everyday life as in telling jokes, asking riddles, responding ironically and expressing humorously different aspects of life. The study of humor has been investigated in different disciplines such as philosophy, sociology, psychology, literature and many others. In Linguistics, humor has received a special focus. Attardo (2011) defines humor as anything that is funny, amusing, or laughable. There are two types of humor: verbal humor and non-verbal humor. The fundamental distinction between these two types lies in the sort of language used to create a sense of humor. Verbal humor emerges by means of language whether spoken or written. Non-verbal humor, on the other hand, falls outside of language; it emerges, for example, from funny actions or gestures.

This study is concerned with verbal humor. Attardo (2020) argues that verbal humor is humor that depends on " semantics (meaning) and similarity or identity of two linguistic forms: phonemic (sounds) or graphemic (spellings)' (p. 26). An example of verbal humor can be found in the following joke taken from Seewoester (2009, p. $5)$ :

Atheism is a non-prophet organization. 
In this joke, verbal humor results from the similar pronunciation of the two words "prophet" and "profit" as well as the different meaning of these words.

Many linguists have highlighted the relationship between ambiguity and humor. Ritchie (2004), for example, points out that " [D] eliberate ambiguity will be shown to underlie much, if not all, of verbal humor " (p. 40). Goatly (2021), also, argues that " [A]mbiguity has been long recognized as essential for most kinds of humor "' (p. 21). Moreover, Giorgadze (2014) strengthens that

humorous or any other effects created by puns depend upon the ambiguities words entail ' (p. 271). This study focuses on how lexical ambiguity is a source of verbal humor in some English jokes and riddles.

\section{The Research Problem}

Reviewing the previous research on how ambiguity creates a sort of humor shows that focusing on lexical ambiguity which is the most pervasive type of linguistic ambiguity as a source of creating verbal humor in jokes and riddles that present the most common form of verbal humor, identifying the ambiguous words that these jokes and riddles contain, classifying them into the forms of lexical ambiguity, i.e. homonymy with its three sub-types (absolute homonymy, homophone and homograph) as well as polysemy, and illustrating how these ambiguous words result in verbal humor in the light of the Incongruity Theory of humor has not been studied yet. Identifying the forms of lexical ambiguity found in jokes and riddles may serve as useful tips helping in understanding and enjoying these jokes and riddles.

\section{Purpose of the Research}

The purpose of this research is to:

a. identify the ambiguous words in the selected jokes and riddles,

b. classify them into the forms of lexical ambiguity, i.e. homonymy with its three sub-types (absolute homonymy, homophone and homograph) and polysemy showing the frequency of each form, and 
c. illustrate how lexical ambiguity can create verbal humor in the selected jokes and riddles in the light of the Incongruity Theory of humor.

\section{Review of the Literature}

Different researchers have investigated the positive role played by linguistic ambiguity in creating humor through their study of different sources. Some researchers have focused on how ambiguity results in humor in newspaper headlines. Bucaira (2004), for instance, analyzed 135 ambiguous headlines that present humorous bits of information finding out that syntactically ambiguous headlines were found in good percentage than the lexical ones. Other researchers have studied ambiguity as a source of humor in comic TV series such as Bhaskoro (2019) who analyzed 13 conversations that contain lexical ambiguity from Mind Your Language TV series of season 1 , episodes 1 and 2 concluding that the multiple meaning that makes different interpretations of the ambiguous words is what causes humor.

Other researchers have made a collection of different sources as their data in studying specific or different types of ambiguity that create humor. Charina (2017), for example, analyzed 25 cases of ambiguity from newspaper headlines, jokes, riddles and anecdotes concluding that lexical ambiguity and syntactic ambiguity are effective language devices to create humor. Gámez (2019) examined 26 sentences from newspaper headlines, advertisements slogans and jokes to illustrate how phonological, lexical, structural and pragmatic ambiguities are sources of humor.

\section{Theoretical Framework}

\subsection{Ambiguity}

\subsubsection{What is Ambiguity?}

Ambiguity is defined as the property of a word or sentence to have more than one meaning (Huang, 2012, p.27). It occurs when a single linguistic form (word, phrase, or sentence) can be interpreted in two or more different ways. For instance, in a sentence like "George bought new glasses", the word "glasses" is ambiguous since it can be interpreted as either "spectacles" or "drinking vessels". Ambiguity is also 
referred to as uncertainty of meaning. Agirre and Edmonds (2007) argue that " when there is uncertainty as to the meaning that a speaker or writer intends, there is ambiguity " (p.8).

Ambiguity is often contrasted with vagueness. Although it appears that the two terms are similar because they allow the probability for more than one interpretation, there are different. Many linguists have clarified the difference between ambiguity and vagueness. Murphy (2010, p. 84), for example, argues that vagueness refers to a word that has one general meaning that can be used for many different things. Consider the following sentences:

(1) There is a child in the garden.

(2) John saw an animal.

In sentence (1), the word "child" is vague; its meaning is general since it can refer to either a male child or a female one. In sentence (2), the word "animal" is vague. It has a general meaning; it can be used to refer to any member of the category of animals. As a result, it is not clear which animal John saw.

Berry and Kamsties (2004, p. 16), also, pinpoint that while ambiguity

" cannot be left undecided ", vagueness " can function as a satisfactory communication "'. This difference can be exemplified as follows:

(3) He owned a pen.

(4) She visited her aunt.

In sentence (3), the word "pen" is ambiguous as it refers either to "writing instrument" or "enclosed place for keeping animals". Such ambiguity cannot be left indeterminate; only one meaning must be selected. In sentence (4), although the word "aunt" is vague as it is not clear whether it refers to "father's sister" or "mother's sister", it works satisfactory. Moreover, Friendrich (2017, p.1) shows that while ambiguity is overdetermined, vagueness is underdetermined. For instance, the verb "play" is ambiguous; its meaning is overdetermined including "play a game", "play music" and "play a role". The adjective "rich" is vague as it is not determined when exactly a person is rich. 
There are different types of ambiguity: lexical ambiguity, syntactic ambiguity, semantic ambiguity and pragmatic ambiguity. This research focuses mainly on lexical ambiguity.

\subsubsection{Lexical Ambiguity}

Lexical ambiguity is the simplest and the most pervasive type of ambiguity. It occurs when a single lexical item has more than one meaning. For example, in a sentence like "John found a bat", the word "bat" is lexically ambiguous as it refers to "an animal" or "a stick used for hitting the ball in some games". Lexical ambiguity is divided into two forms: homonymy and polysemy. Murphy (2010, p. 84) distinguishes between these two forms arguing that when two words have the same spoken and/or written form but have different unrelated meanings, it is a case of homonymy, but when a single word has different related meanings, it is a case of polysemy. The following section illustrates these two forms.

\subsubsection{Homonymy}

Homonymy occurs when words have the same spelling and/or pronunciation of other words but different unrelated meanings. It includes three sub-types: homophones, homograph and absolute. A distinction between these three sub-types can be shown as follows:

\section{a. Homophones:}

Homophones are words that have the same pronunciation but different spellings and different meanings. For example, the words "flour" and "flower" are homophones as both pronounced the same /flavo/, but they have different meaning: "flour" means "powder made from grain" and "flower" means "part of a plant". Other examples of homophones include the words: (see/sea) both pronounced as /si:/, (tail/tale) both pronounced as /terl/ and (whether/weather) both pronounced as /weðə/, but words in each pair have different meaning.

\section{b. Homographs:}

Homographs are words that have the same spelling but different pronunciations and different meanings. For example, 
the word "bow" is a homograph since it can be pronounced in two different ways with two different meanings. The first pronunciation is /bav/ which means "the front part of a ship" whereas the second pronunciation is /bəv/ which means "a weapon for shooting arrows". Other examples of homographs include words such as "wind" pronounced as /wind/ and /waind/, "minute" pronounced as /minit/ and /mai'nju:t/, and "lead" pronounced as /li:d/ and /led/. In these examples, each pronunciation of a word has a different meaning.

\section{c. Absolute homonymy}

Absolute homonymy occurs when words have the same spelling and pronunciation, but different meanings. The word "lie" is an example of absolute homonymy; it has one written and spoken form but two different meanings as it means either "a position of body in flat" or "to speak falsely". Similarly, the word "mouse" is a case of absolute homonymy. Although it has the same spelling and pronunciation, it refers to two different meanings, i.e. a small furry animal with a long tail or a small handheld input device that controls a computer screen's cursor. Many words are absolute homonyms such as "bank", "park", and "bat".

\subsubsection{Polysemy}

Polysemy occurs when a word has different related meanings. The word "head", for example, is a case of polysemy; its different meanings as "leader of a group" and "part of the body" are related as they have the same sense of being top of something. Other examples of polysemous nouns include "foot" which refers to "the part of the body at the bottom of a leg" or "bottom of an object" such as foot of a cliff and foot of the page, "newspaper" which means either "paper material object" or "organization publishing newspaper", and "wood" which refers to "material" or "an area of land covered with trees".

\subsection{Humor}

\subsubsection{What is Humor?}

Humour is something that we all encounter or use ourselves in our everyday 
Humor is a common aspect of everyday life since people tend to tell jokes, reply ironically to some questions, and mock each other in a humorous way (Alharthi, 2016, p. 6). Vandaele (2010) defines humor as " what causes amusement, mirth, a spontaneous smile and laughter " (p. 147). In other words, humor is anything that tends to get people relax, cause a smile and elicit happiness. However, humor can also be used to increase tension, humiliate, or lessen motivation such as the case in sarcastic humor. Humor may occur in situations where there are at least two individuals: the humor initiator or the sender and the receiver, or in a situation where a single individual confronts a perceived incongruity.

Humour is what causes

\subsubsection{Types of Humor}

There are two types of humor: verbal humor and nonverbal humor. Harida (2018, p. 79) distinguishes between these two types of humor arguing that while the former exploits linguistic forms such as words, phrases and sentences, the latter exploits behaviors, physical appearances and events. In other words, verbal humor emerges from the use of language whether spoken or written, but non-verbal humor emerges from the use of non-verbal language such as gestures and body language. This research focuses on verbal humor where there are at least two different meanings that are combined in a text in a way that leads the receiver to expect one meaning, but he experiences the other. The common instances of this type of humor are jokes and riddles.

\subsubsection{Theories of Humor}

There are numerous theories of humor. Among these theories, there are three leading ones: the Superiority Theory, the Relief or Release Theory and the Incongruity Theory. Here is a brief account of each theory with a special focus on the Incongruity Theory.

a. The Superiority Theory

This theory dates back to Plato and Aristotle and was put forth by Thomas Hobbes. It views humor as " a feeling of superiority over someone else " (Marsh, 2019, p.212). According to this theory, humor results when someone 
ridicules, humiliates or disparages someone else as an expression of superiority. Humor, in this sense, provokes hostility; therefore, it is dissociated from its major aim which is to amuse. The Superiority Theory cannot account for all humorous situations as not all humorous situations have negative effects.

b. The Relief or Release Theory

This theory was introduced by Sigmund Freud and framed by Herbert Spencer. It suggests that humor results from " reducing stress or tension", allowing " release of nervous energy "' (Meyer, 2015, p.13). In other words, humor is a way through which people could overcome unpleasant emotions and feel relieved. The Relief Theory is widely accepted as it stresses the psychological benefits of humor.

c. The Incongruity Theory

This theory was formulated by James Beattie. It is claimed that it is the best theory of humor. Smuts (2006), for example, argues that it is " the reigning theory of humor" ( $p$. 91). The basic assumption of this theory is that the perception of incongruity is the source of humor. In this context, Ghodsi and Heidari-Shahreza (2016) explain that " humor is perceived at the moment of realization of incongruity between a concept involved in a certain situation and the real objects thought to be in some relation to the concept " (p. 175). In other words, humor results when there is a conflict between what is expected from a certain situation and what actually occurs.

Therefore, according to the incongruity theory, people perceive something to be amused or humorous when they find it incongruous with what they think the normal order of things. People believe that things interact with each other in a normal, consistent and ordered way. Once there is an experience that does not match with this ordered way, humor arises. Thus, humor is seen as " unexpected or surprising experiences, words, or activities that happen " (Jonas, 2004, p.57). It is worth noting that incongruity is not sufficient to create humor, but it is a necessary condition. Moreover, 
humor results not from incongruity but from realizing and resolving such incongruity.

\section{Research Questions}

This research attempts to answer the following questions:

1. What are the forms of lexical ambiguity that the ambiguous words contained in the selected jokes and riddles represent?

2. What is the frequency of each form of lexical ambiguity as represented in the selected jokes and riddles?

3. How does lexical ambiguity involved in the selected jokes and riddles result in humorous effects in the light of the Incongruity Theory of humor?

\section{Methodology}

The research employs a qualitative-quantitative method of data analysis. It follows a qualitative method since it seeks to provide a description of the phenomenon that lexical ambiguity creates humor. This is done through analyzing 20 examples of jokes and riddles that were taken from three internet sites: https://www.riddles.com/, https://riddles.tips/ which are top riddles sites ( https://www.top20sites.com/topriddles-sites) and https://www.funology.com/. The choice of jokes and riddles is based on the presence of words that contain lexical ambiguity. The meanings of the ambiguous words are taken from Cambridge Learner's Dictionary $4^{\text {th }}$ edition. Classifying the meanings of the ambiguous words into polysemous or homonymous depends on MerriamWebster Online Dictionary where polysemous meanings are listed under the same entry while homonymous ones are given separate entries.

The data analysis depends on the Incongruity Theory of humor as a framework to illustrate how lexical ambiguity creates humor in the selected jokes and riddles. The reason for choosing this theory is that it is " the most often-used theory in humor research", and it accounts for " most cases of funniness " (Cayanus \& Martin, 2016, p. 215). The Incongruity Theory emphasizes that humor results from unexpected or contradictory connections as well as the 
inconsistency or incongruity between things. Also, the research follows a quantitative method since the results of the data analysis have been presented in numbers and tables showing the forms of lexical ambiguity that the ambiguous words represent as well as the frequency of each form.

\section{Data Analysis}

The 20 examples of jokes and riddles are analyzed to identify the ambiguous words in the selected jokes and riddles, classifying them into the forms of lexical ambiguity, i.e. homonymy with its three sub-types (absolute homonymy, homophone and homograph) and polysemy showing the frequency of each form and to show how lexical ambiguity can create humor. The analysis is carried out as follows:

(1) Q: What has a head, a tail, is brown, and has no legs?

\section{A: A Penny.}

(Source: https://www.riddles.com /504)

This riddle plays on the different meanings of the ambiguous words: "head" and "tail". Among their different meanings, the word "head" means "the part of the body above the neck", and the word "tail" means "a part of an animal's body". Having these meanings of the two words, a hearer may find it humorous. Humor, here, is created from the incongruity between having a head and a tail and not having legs.

The answer of the riddle shows that the previous meanings of the words "head" and "tail" are not the intended ones. It depends on having the meaning "the front side of a coin that has a picture on it" for the word "head" and "the back side that does not have a picture on it" for the word "tail". The words "head" and "tail", having these different unrelated meanings, are a case of absolute homonymy.

(2) $Q$. What has many keys, but can't even open a single door?

A. A piano.

(Source: https://www.riddles.com/ 2355)

The ambiguity in this riddle is created by the ambiguous word "keys". "Keys" may refer to "pieces of metal that are used for opening or closing a lock" or "the moving parts that you press with your fingers on a computer, typewriter or 
musical instruments". Having the first meaning of the word "keys", this riddle becomes humorous because it violates someone's knowledge that keys are used to open doors. The answer of the riddle seems to be based on the second meaning. The word "keys" presents a case of absolute homonymy with its different unrelated meanings.

\section{(3) Q: Which building has the most stories?}

\section{A: A library}

(Source: https://www.riddles.com/1654)

This riddle depends on the word "stories" which is ambiguous through absolute homonymy. The word "stories" may refer to "connected series of events" or "level of building". Humor is found in the answer of the riddle as it seems to depend on the first meaning that does not match with the question that implies the second one. In other words, humor arises because of the unexpected answer that does not fix the speaker's desire to know the building that has the most levels.

\section{(4) Q: Why was 6 afraid of 7?}

\section{A: Because 78 9!}

(Source: https://www.riddles.com/3098)

In the answer of the riddle, the word "eight", being a homophone to the word "ate" (the past tense of the verb "eat") as both pronounced as /eit/, is what makes the answer of the riddle humorous. Humor, here, results from the unexpected answer that depends on the sound of the word "eight" to mean the verb "ate".

(5) Q: What runs around the whole yard without moving?

\section{A. A fence.}

(Source: https://www.riddles.com/ 1942)

The word "run" is the key point in forming this riddle. As a verb, one of the most common meanings of "run" is to "go quickly". Having this meaning makes the question of this riddle humorous. Humor, in this case, is created by the unexpected and surprising connection between "runs" and "without moving" which contradicts with one's belief that what is running is moving. The answer of the riddle seems to be based on the meaning of the verb "run" as "to extend in 
relation to something". Hence, this riddle depends on the verb "runs" that is ambiguous through absolute homonymy; its two different meanings are unrelated.

(6) Q: What is the difference between a coat and a baby?

A: The one you wear, the other you were.

(Source: https://www.riddles.com/ 1978)

The answer of the riddle plays on the homophones "wear" and "were" that share the same sound /we:/. The humorous effect, found in the answer, is created from the unexpected answer. On hearing the question, the hearer begins to think of a serious difference between a coat and a baby not expecting that the answer plays on the sound /we:/ for two words with different spelling and meanings.

(7) Q. Why does the teacher wear sunglasses when she comes to the class?

A. Because the students are bright.

(Source: https://www.riddles.com/1247)

The answer of the riddle plays on the meanings of the ambiguous word "bright" which means either "full of light, shining" or "intelligent". Ambiguity, here, results from absolute homonymy. Humor arises when the hearer, depending on the first meaning, interprets the answer as "the teacher's students are full of light" making a connection between this meaning and the word "sunglasses" in the question of the riddle. However, this interpretation violates someone's knowledge that students are not lightening objects. The serious interpretation of the answer is " the teacher's students were intelligent"

(8) $Q$. Why do skeletons go on vacations alone?

\section{A. Because they have no-body to go with.}

(Source: https://www.riddles.com/ 2202)

The sound /'nərbədi/ for the two words "nobody" which means "not a single person" and "no body" which means "not having a body" is the key point for creating humor in the answer of the riddle. The hearer may take the sound /'nəobədi/ for the word "nobody" interpreting the answer as "skeletons do not have persons to go to vacations with". This interpretation is humorous suggesting that skeletons are living people having persons sharing them doing things. This is not true. The serious 
interpretation for the answer is that "skeletons do not have bodies".

(9) Q: What is black and white and read all over?

A: A newspaper!

(Source: https://riddles.tips/riddle-228)

The question of the riddle is ambiguous; it plays on the sound /red/ that can be taken as the sound of the word "red" (adjective) or the word "read" (the past participle of the verb "read"). Humor arises when the hearer takes the sound /red/ for the color "red" after hearing the colors "black" and "white" getting surprised when he/she finds the answer of the riddle depends on the sound /red/ for the past participle of the verb "read".

(10)Q. What can you catch but never throw?

\section{A. A cold.}

(Source: https://riddles.tips/riddle-58)

This riddle depends on the ambiguous verb "catch". Having the meaning of the verb "catch" as "take hold", the question of the riddle becomes humorous as it implies that there is something that can be caught but not thrown. Humor, here, arises from the contradiction with the fact that what can be hold can also be thrown. The answer of the riddle, "cold", is an unexpected answer; it depends on the meaning of "catch" as "become infected". Hence, the ambiguity, here, is expressed through absolute homonymy.

\section{(11) Q: What has one eye but cannot see?}

\section{A: A needle}

(Source: https://riddles.tips/riddle-103)

This riddle plays on the meanings of the word "eye" that is ambiguous through absolute homonymy. Having the meaning of "eye" as "a body part which one uses to see with" creates humor which results from the inconsistency between 'having eyes' and 'not having the ability to see'. The answer of the riddle depends on the meaning of "eye" as "the hole in a needle through which one puts the thread".

\section{(12) Q: What has hands but cannot clap?}

\section{A: A clock.}

(Source: https://riddles.tips/riddle-596) 
The question of this riddle is ambiguous; it depends on the word "hands" as its key point. Among its several meanings, the word "hands" may mean "the part of the body at the end of the arm". Having this meaning, the question of the riddle creates a sort of humor because of the incongruity between 'having hands' and 'not having the ability to clap'. The answer of the riddle seems to be based on the meaning of "hands" as "the long, thin pieces that point to the numbers on a clock or watch". It is the clock that has three hands: hour hand, minute hand and second hand, and it does not clap. The two different but related meanings, in some sense, of the word "hands" implied in this riddle represents a case of polysemy.

\section{(13) Q: What has a neck but no head?}

\section{A: A shirt.}

(Source: https://riddles.tips/riddle-194)

This riddle depends on the word "neck" that is ambiguous through polysemy having the two meanings: "the part of the body that joins the head to the shoulders" and "the part of a piece of clothing which goes around a person's neck". Having the first meaning of the word "neck", the hearer finds it humorous to have a neck without a head which is surprising and unexpected. The answer of the riddle, "shirt", depends on the second meaning.

\section{(14) Q: I am a king who's good at measuring stuff. What am I?}

\section{A. Ruler.}

(Source: https://riddles.tips/riddle-899/)

This riddle plays on the different meanings of the word "king" that is ambiguous through polysemy. It means either "a male ruler" or "the most important of a group of things". Humor is found in the answer of the riddle as the hearer may associate the meaning of "ruler" as "a leader" to the first meaning of the word "king". However, the meaning of "ruler" as "an instrument for drawing" is what fixes the intended meaning of "king" implied in the question.

\section{(15) Q: When should you buy a bird?}

\section{A: When it's going cheep!}

(Source: https://www.funology.com/bird-jokes/) 
The similar sounds of the words "cheep" and "cheap" are the key points of this joke. These two words are homophones with the same sound but different meanings. As a result, the two-way interpretation of the answer of the joke creates a sense of humor. One hearer may take the sound $/ \mathrm{t} f \mathrm{i}: \mathrm{p} /$ for the word "cheap". In this case, the answer of the question can be interpreted as "one should buy a bird when its price is low". Another hearer may take the sound / $\mathrm{t} \mathrm{i}: \mathrm{p} /$ for the word "cheep". In this case, the answer can be interpreted as "one should buy a bird when it makes a short, squeaky sound". It is clear that the first interpretation is the serious interpretation while the second is the humorous one; it is an unexpected answer to when one should buy a bird.

\section{(16) Q: Why do cows have bells?}

\section{A: Because their horns don't work!}

(Source: https://www.funology.com/animal-jokes/)

This joke plays on the ambiguous word "horn" that has a double meaning: "a hard, pointy things that grow on the head of some animals" or "a device that is used to make a loud voice". The ambiguity, here, depends on absolute homonymy. Humor results in the answer of the riddle if it is interpreted as "cows have horns such as the car horns to make voice, but these horns do not work". This is not true. The serious interpretation of the answer is that "the horns on the head of cows do not work as bells"

\section{(17) Q: How do you keep an elephant from charging?}

\section{A: Take away its credit cards!}

(Source: https://www.funology.com/animal-jokes/)

This joke plays on the ambiguous word "charge" which is a case of absolute homonymy. The verb "charge" has several different meanings such as "to ask an amount of money for something", "accuse formally", "order" and "to move forward". The answer of the joke becomes humorous since it depends on the meaning of "to ask an amount of money for something" which is not intended by the question that implies the meaning "to move forward". 
(18) Q: What kind of cat should you never play games with?

\section{A: A cheetah!}

(Source: https://www.funology.com/animal-jokes/)

This joke depends on the homophones "cheetah" and "cheater" that sound the same /' $\mathrm{t} f \mathrm{i}$ :to/ but have different meanings. One hearer may take the sound /' $\mathrm{t} \mathrm{ji}$ :ta/ for the word "cheetah", a wild animal of the cat family, connecting it with the word "cat" found in the question of the joke while another hearer may take it for the word "cheater" associating it with "play games". Humor arises when taking the sound /' $\mathrm{t} f \mathrm{i}$ : $\mathrm{t} /$ for the word "cheater" as it is not expected that a cat can cheat in playing games.

(19) Q: Which day do fish hate?

\section{A: Fryday!}

(Source: https://www.funology.com/animal-jokes/)

The sound/fraideI/ is what causes ambiguity in the answer of this joke as it is the sound of two homophones "Friday", the day of the week after Thursday, and "fry day". Humor arises when the word "Friday" is taken for the sound /fraideI/ as it seems surprising and not expected that fish hate Friday and like the other days of the week. The sound /fraideI/ is taken for the two words "fry day". Thus, the answer of the joke can be understood as "fish hate the day when they are fried".

\section{(20) Q: What nails do carpenters hate to hit?}

\section{A: Fingernails.}

(Source: https://www.funology.com/other-jokes-and-riddles)

This joke plays on the ambiguous word "nail" that has two different meanings: "a small thin piece of metal" and "body part". Here, the ambiguity is based on absolute homonym. The answer of the joke, fingernails, becomes humorous; it is an unexpected answer since it depends on the second meaning of the word "nail" while the question implies the first meaning.

\section{Results and Discussion}

The analysis of the research data reveals that the jokes and riddles selected are based on lexically ambiguous words 
that represent the two forms of lexical ambiguity: homonymy (words that have different unrelated meanings) and polysemy (words that have different but related meanings) as shown in "Appendix A". In item 3, for example, the word "nails" is lexically ambiguous through homonymy; its two meanings as a "small thin piece of metal" and "body part" are different and unrelated. Item 15, for instance, contains the ambiguous word "neck" that represents a case of polysemy as its meanings as "the part of the body that joins head to the rest of the body" and "the part of a piece of clothing which goes around a person's neck ", though different, are related in some sense. The following table shows the frequency of each form of lexical ambiguity:

Table 1. Frequency of the two types of lexical ambiguity

\begin{tabular}{|c|c|c|c|}
\hline No. & $\begin{array}{c}\text { Forms of Lexical } \\
\text { Ambiguity }\end{array}$ & $\begin{array}{c}\text { Number of } \\
\text { Jokes/Riddles }\end{array}$ & Percentage \\
\hline 1 & Homonymy & 17 & $85 \%$ \\
\hline 2 & Polysemy & 3 & $15 \%$ \\
\hline \multicolumn{2}{|c|}{ Total } & $\mathbf{2 0}$ & $\mathbf{1 0 0 \%}$ \\
\hline
\end{tabular}

Table (1) shows that $85 \%$ of the jokes and riddles are ambiguous through homonymy whereas $15 \%$ are ambiguous through polysemy. Thus, it can be concluded that homonymy is the most frequent form of lexical ambiguity represented in the selected jokes and riddles while polysemy is the least frequent one.

As for the sub-types of homonymy, only absolute homonymy and homophone are found while homograph is not. Absolute homonymy occurs when a single word has the same sound and spelling but different meanings. The verb "runs" in item 5, for example, is a case of absolute homonymy as it has the same sound and spelling but different meanings; it means either "go quickly" or "to extend in relation to something". Homophones are two words that sound the same, but they have different spellings and different meanings. The words "were" and "wear" in item 6 are a case of homophones. The frequency of the sub-types of homonymy can be illustrated in the following table:

Table 2. Frequency of the sub-types of homonymy 


\begin{tabular}{|c|c|c|c|}
\hline No. & $\begin{array}{c}\text { The Sub-types of } \\
\text { Homonymy }\end{array}$ & $\begin{array}{c}\text { Number of } \\
\text { Jokes/Riddles }\end{array}$ & Percentage \\
\hline 1 & Homophone & 7 & $41.1 \%$ \\
\hline 2 & Homograph & 0 & $0 \%$ \\
\hline 3 & $\begin{array}{c}\text { Absolute } \\
\text { Homonymy }\end{array}$ & 10 & $58.9 \%$ \\
\hline \multicolumn{2}{|c|}{ Total } & $\mathbf{1 7}$ & $\mathbf{1 0 0 \%}$ \\
\hline
\end{tabular}

As shown in table 2, 58.9\% of the jokes and riddles contain ambiguous words that represent absolute homonymy while $41.1 \%$ represent homophones, but no jokes or riddles contain ambiguous words that represent homograph. Therefore, absolute homonymy is the most frequent sub-type of homonymy.

Moreover, the data analysis shows that lexical ambiguity found in the selected jokes and riddles creates humor. According the Incongruity theory of humor, humor arises from incongruity or inconsistency between things. This becomes clear in item 12, for example, where 'having hands' and 'not having the ability to clap' seems incongruous. Also, this theory emphasizes that humor results from unexpected responses. In item 4, for instance, humor, found in the answer of the riddle "Because seven eight nine", is unexpected; it depends on the sound /eit/ taken for the past tense "ate" not for the number "eight". Moreover, humor comes as a reaction to something that violates one's previously set-up experiences or knowledge. This is apparent in item 2 where 'keys cannot open a single door' violates one's knowledge that keys are used to open doors.

It is worth noting that in the jokes and riddles selected, it is one meaning of the ambiguous words that creates humor either in the question or in the answer of the joke/riddle making the joke/riddle ambiguous while another meaning of these ambiguous words resolves the ambiguity of joke/riddle making it funny. For example, in item 10, having the meaning of the verb "catch" as "get hold of" creates humor and makes the riddle ambiguous while having the meaning "become infected" resolves this ambiguity. The result of this research comes in accordance with the results of Wang (2018) who argues that ambiguity is the most important source of verbal 
humor bringing a lot of it. Also, he explains that ambiguity results in humor because of the cash of different meanings that are understood in a wrong, incongruous way.

\section{Conclusion}

This research seeks to answer three questions. The first one is: "What are the forms of lexical ambiguity that the ambiguous words contained in the selected jokes and riddles represent?". The results show that the words that contain lexical ambiguity in the selected jokes and riddles are of the two forms of lexical ambiguity, i.e. homonymy and polysemy. The second question is: "What is the frequency of each form of lexical ambiguity as represented in the selected jokes and riddles?". The results reveal that homonymy represents $85 \%$ of the selected jokes and riddles whereas polysemy represents $15 \%$. Thus, it can be concluded that homonymy is the most frequently used form of lexical ambiguity that results in humor in the selected jokes and riddles, where absolute homonymy $(58.9 \%)$ is the most used. The third question is: "How does lexical ambiguity involved in the selected jokes and riddles result in humorous effects in the light of the Incongruity Theory of humor?". The results show that lexical ambiguity creates humor in the jokes and riddles selected due to the incongruity and inconsistency of ideas as well as the unexpected, surprising responses.

\section{References}

Agirre, E. \& Edmonds, P. (Eds.). (2007). Word Sense Disambiguation: Algorithms and Applications. Springer.

Alharthi, A. A. (2016). Challenges and Strategies of Subtitling Humour: A Case Study of the American Sitcom Seinfeld, with Particular Reference to English and Arabic. [Doctoral dissertation, University of Salford]. https://www.semanticscholar.org > paper

Attardo, S. (2011). Humor. In J. Zienkowski, J. Ostman, \& J. Verschueren (Eds.), Discursive Pragmatics (pp. 135-155). John Benjamins Publishing Company.

Attardo, S. (2020). The Linguistics of Humor: An Introduction. Oxford University Press. 
Baker, G. (2016). 'Do you get it' An Investgation into the Different Types of Ambiguity English-Speaking Children (Aged 6-11) Are Able to Comprehend in Verbal Riddles. [Doctoral dissertation, Cardiff University]. https://orca.cf.ac.uk

Berry, D. M. \& Kamsties, E. (2004). Ambiguity in Requirements Specification. In J. C. Pradoleite \& J. H. Doorn (Eds.), Perspectives on Software Requirements (pp. 7-44). Springer Science\& Business Media.

Bhaskoro, C. H. (2019). Lexical Ambiguity Resulting in Mind Your Language TV Series of Season 1 Episodes 1 and 2. [Undergraduate Thesis]. Universitas Sanata Dharma. http://repository.usd.ac.id > 2 > 154214036 full

Bucaria, C. (2004). Lexical and Structural Ambiguity in Humorous Headlines. [Master's thesis, Youngstown State University].

http://uxxi.yolasite.com > resources > Bucaria Lex...

Cayanus, J. \& Martin, M. (2016). Humor Enactment in Learning Environments. In P. L. Witt (Ed.). Communication and Learning (pp. 211-240). Walter de Gruyter Inc.

Charina, I. N. (2017). Lexical and Syntactic Ambiguity in Humor. International Journal of Humanity Studies, 1(1), 12-131.

https://ejournal.usd.ac.id/index.php/IJHS/article/view/681 Friedrich, G. (2017). On the Difference Between Ambiguity, Vagueness and Indeterminacy. https://www.researchgate.net

Gámez, M. R. (2019). Linguistic Ambiguity as a Resource for Humor. [end-of-degree thesis, Universidad De Jaen]. https://www.semanticscholar.org > paper

Giorgadze, M. (2014). Linguistic Features of Puns, its

Typology and Classification. European Scientific Journal,

2, 271-275. https://www.researchgate.net > 327106

Ghods, F. \& Heidari-Shahreza, M. A. (2016). A Relevancetheoretic Analysis of Persian Verbal Humor and Online Joking. Journal of Applied Linguistics and Language Research, 3(7), 174-182. 
Goatly, A. (2012). Meaning and Humor. Cambridge University Press.

Harida, R. (2018). Analysis of Humor Making Techniques in the WIT Comedy Program (Waktu Indonesia Timur). International Journal of Education, Information Technology, and Others, 1(2), 78-85. https://jurnal.unibrah.ac.id > view

Huang, Y. (2012). The Oxford Dictionary of Pragmatics. Oxford University Press.

Jonas, P. M. (2004). Secrets of Connecting Leadership and Learning with Humor. ScarecrowEducation.

Marsh, M. (2019). American Jokes, Pranks, and Humor. In S. J. Bronner (Ed.). The Oxford Handbook of American Folklore and Folklife Studies (pp. 210-233). Oxford University Press.

McGregor, W. B. (2015). Linguistics: An Introduction (2 ${ }^{\text {nd }}$ ed.). Bloomsbury.

Meyer, J. C. (2015). Understanding Humor Through Communication: Why Be Funny, Anyway? Lexington Books.

Murphy, M. L. (2010). Lexical Meaning. Cambridge University Press

Ritchie, G. (2004). The Linguistic Analysis of Jokes. Routledge.

Seewoester, S. (2009). Linguistic Ambiguity in Languagebased Jokes. [Master's thesis, DePaul University]. http://via.library.depaul.edu/

Smuts, A. (2006). Laughing at Art: Humor, Art and Morality. University of Wisconsin.

Vandaele, J. (2010). Humor in translation. In Y. Gambier \& V. L. Doorslaer (Eds.), Handbook of translation studies (Vol.3, pp.146-152). John Benjamins Publishing Company.

Wang, W. (2018). Linguistic Formation-Mechanism of Humor in English. Advances in Intelligent Systems Research, 163, 126-130. https://download.atlantispress.com 
Appendix A: Ambiguous words contained in the selected jokes/riddles

\begin{tabular}{|c|c|c|c|}
\hline $\begin{array}{c}\text { No. of } \\
\text { Joke/ } \\
\text { Riddle }\end{array}$ & $\begin{array}{l}\text { Ambiguous } \\
\text { Word(s) }\end{array}$ & $\begin{array}{l}\text { Reason for Being } \\
\text { Ambiguous }\end{array}$ & $\begin{array}{c}\text { Form of } \\
\text { Lexical } \\
\text { Ambiguity }\end{array}$ \\
\hline 1 & head & $\begin{array}{l}\text { It has multiple meanings } \\
\text { such as: } \\
\text { 1. the part of the body } \\
\text { above the neck } \\
\text { 2. the front side of a coin } \\
\text { that has a picture on it } \\
\text { It has multiple meanings } \\
\text { such as: } \\
\text { 1. a part of an animal's } \\
\text { body } \\
\text { 2. the back side that does } \\
\text { not have a picture on it }\end{array}$ & $\begin{array}{l}\text { Homonymy } \\
\text { "Absolute" } \\
\text { Homonymy } \\
\text { "Absolute" }\end{array}$ \\
\hline 2. & Keys & $\begin{array}{l}\text { It has multiple meanings } \\
\text { such as: } \\
\text { 1. pieces of metal that are } \\
\text { used for opening or } \\
\text { closing a lock } \\
\text { 2. the moving parts that } \\
\text { you press with your } \\
\text { fingers on a computer, } \\
\text { typewriter or musical } \\
\text { instruments }\end{array}$ & $\begin{array}{l}\text { Homonymy } \\
\text { "Absolute" }\end{array}$ \\
\hline 3. & stories & $\begin{array}{l}\text { It has multiple meanings } \\
\text { such as } \\
\text { 1. connected series of } \\
\text { events } \\
\text { 2. level of building }\end{array}$ & $\begin{array}{l}\text { Homonymy } \\
\text { "Absolute" }\end{array}$ \\
\hline 4. & 8 & $\begin{array}{l}\text { It is pronounced as "ate"; } \\
\text { both have the same sound } \\
\text { /eit/. }\end{array}$ & $\begin{array}{l}\text { Homonymy } \\
\text { "Homophone" }\end{array}$ \\
\hline 5. & runs & $\begin{array}{l}\text { It has multiple meanings } \\
\text { such as } \\
\text { 1. go quickly } \\
\text { 2. to extend in relation to } \\
\text { something }\end{array}$ & $\begin{array}{l}\text { Homonymy } \\
\text { "Absolute" }\end{array}$ \\
\hline 6. & wear, were & $\begin{array}{l}\text { Both words sound the same } \\
\text { /we:/. }\end{array}$ & $\begin{array}{l}\text { Homonymy } \\
\text { "Homophone" }\end{array}$ \\
\hline 7. & bright & $\begin{array}{l}\text { It has multiple meanings } \\
\text { such as } \\
\text { 1. full of light, shining }\end{array}$ & $\begin{array}{l}\text { Homonymy } \\
\text { "Absolute" }\end{array}$ \\
\hline
\end{tabular}




\begin{tabular}{|c|c|c|c|}
\hline & & 2. intelligent & \\
\hline 8. & no body & $\begin{array}{l}\text { It has the same sound as the } \\
\text { word "nobody"; both are } \\
\text { pronounced as /'nəobədi/. }\end{array}$ & $\begin{array}{l}\text { Homonymy } \\
\text { "Homophone" }\end{array}$ \\
\hline 9. & read & $\begin{array}{l}\text { It is pronounced as the word } \\
\text { "red". } \\
\text { Both words have the sound } \\
\text { /red/. }\end{array}$ & $\begin{array}{l}\text { Homonymy } \\
\text { "Homophone" }\end{array}$ \\
\hline 10. & catch & $\begin{array}{l}\text { It has multiple meanings } \\
\text { such as } \\
\text { 1. take hold } \\
\text { 2. become infected }\end{array}$ & $\begin{array}{l}\text { Homonymy } \\
\text { "Absolute" }\end{array}$ \\
\hline 11. & eye & $\begin{array}{l}\text { It has multiple meanings } \\
\text { such as } \\
\text { 1. a body part which one } \\
\text { uses to see with } \\
\text { 2. the hole in a needle } \\
\text { through which one puts } \\
\text { the thread }\end{array}$ & $\begin{array}{l}\text { Homonymy } \\
\text { "Absolute" }\end{array}$ \\
\hline 12. & hands & $\begin{array}{l}\text { It has multiple meanings } \\
\text { such as } \\
\text { 1. the part of the body at } \\
\text { the end of the arm } \\
\text { 2. the long, thin pieces that } \\
\text { point to the numbers on } \\
\text { a clock or watch }\end{array}$ & Polysemy \\
\hline 13. & neck & $\begin{array}{l}\text { It has multiple meanings } \\
\text { such as } \\
\text { 1. the part of the body that } \\
\text { joins the head to the } \\
\text { shoulders } \\
\text { 2. the part of a piece of } \\
\text { clothing which goes } \\
\text { around a person's neck }\end{array}$ & Polysemy \\
\hline 14. & $\begin{array}{l}\text { king } \\
\text { ruler }\end{array}$ & $\begin{array}{l}\text { It has multiple meanings } \\
\text { such as } \\
\text { 1. a male ruler } \\
\text { 2. the most important of a } \\
\text { group of things } \\
\text { It has multiple meanings } \\
\text { such as } \\
\text { 1. a leader } \\
\text { 2. an instrument for } \\
\text { drawing }\end{array}$ & $\begin{array}{l}\text { Homonymy } \\
\text { "Absolute" }\end{array}$ \\
\hline
\end{tabular}




\begin{tabular}{|c|c|c|c|}
\hline 15. & cheep & $\begin{array}{l}\text { It has the same sound as } \\
\text { "cheap"; both are } \\
\text { pronounced as /tfi:p/. }\end{array}$ & $\begin{array}{l}\text { Homonymy } \\
\text { "Homophone" }\end{array}$ \\
\hline 16. & horn & $\begin{array}{l}\text { It has multiple meanings } \\
\text { such as } \\
\text { 1. a hard, pointy things } \\
\text { that grow on the head of } \\
\text { some animals } \\
\text { 2. a device that is used to } \\
\text { make a loud voice }\end{array}$ & $\begin{array}{l}\text { Homonymy } \\
\text { "Absolute" }\end{array}$ \\
\hline 17. & charge & $\begin{array}{l}\text { It has multiple meanings } \\
\text { such as } \\
\text { 1. to ask an amount of } \\
\text { money for something } \\
\text { 2. to move forward }\end{array}$ & $\begin{array}{l}\text { Homonymy } \\
\text { "Absolute" }\end{array}$ \\
\hline 18. & cheetah & $\begin{array}{l}\text { It has the same sound as } \\
\text { "cheater"; both are } \\
\text { pronounced as /'tfi:to/. }\end{array}$ & $\begin{array}{l}\text { Homonymy } \\
\text { "Homophone" }\end{array}$ \\
\hline 19. & fryday & $\begin{array}{l}\text { It has the same sound as } \\
\text { "Friday"; both are } \\
\text { pronounced as / frardeI/. }\end{array}$ & $\begin{array}{l}\text { Homonymy } \\
\text { "Homophone" }\end{array}$ \\
\hline 20. & nail & $\begin{array}{l}\text { It has multiple meanings } \\
\text { such as } \\
\text { 1. a small thin piece of } \\
\text { metal } \\
\text { 2. body part }\end{array}$ & $\begin{array}{l}\text { Homonymy } \\
\text { "Absolute" }\end{array}$ \\
\hline
\end{tabular}




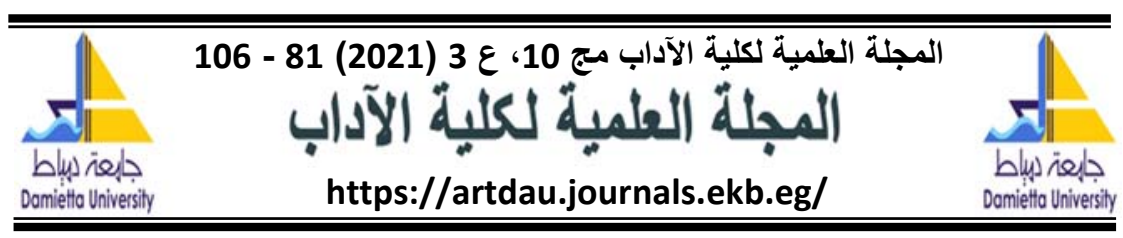

\section{الغموض المعجمي والاعابة اللفظية في بعض النكات والألغاز الإنجليزية}

ريهام عبدالكريم عبد الحميد مكروم

مدرس مساعد ـ قسم اللغة الانجليزية ـ كلية الآداب ـ جامعةم دمياط. المستخلص الصن

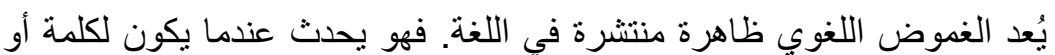

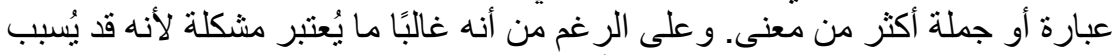

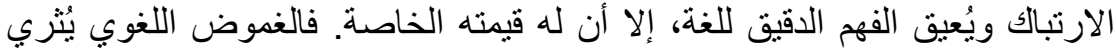

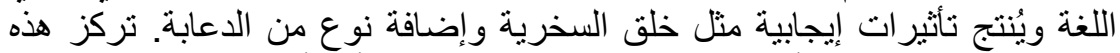

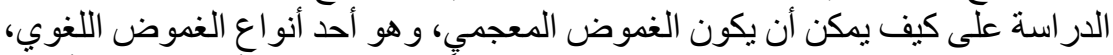

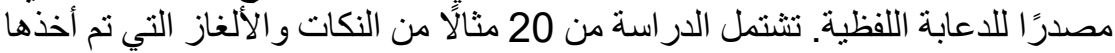

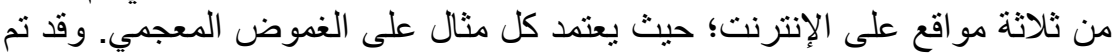

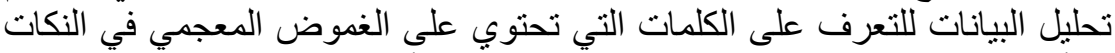

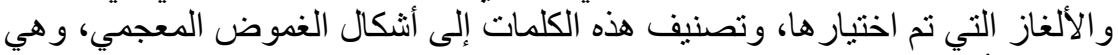

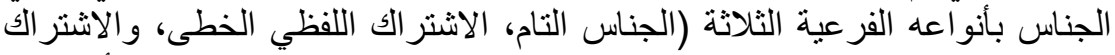

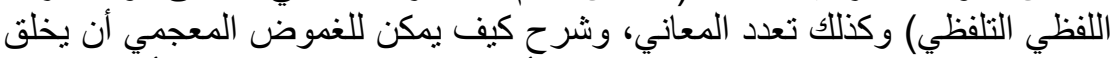

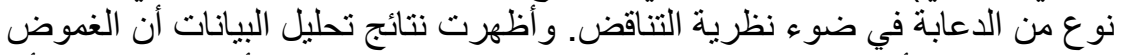

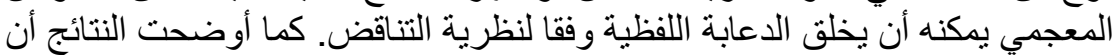

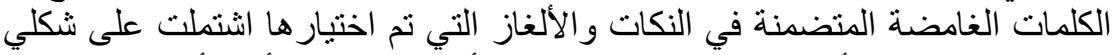

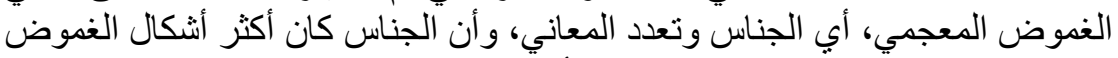
المعجمي شيو عًا بينما تعدد المعي المعاني كان الأقل. الكلمات المفتاحية: المعيو

الغموض المعجمي، الدعابة اللفظية، الجناس التام، الاشتر الك اللفظي التلفظي،

تعدد المعاني

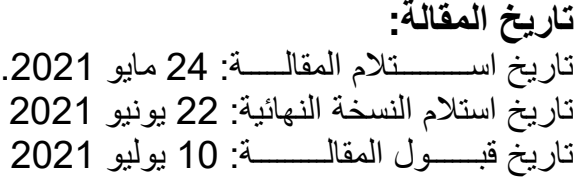

